\title{
Floristic classification of the vegetation in small wetlands of Kenya and Tanzania
}

\author{
Miguel Alvarez, Mathias Becker, Beate Böhme, Collins Handa, Matthias Josko, Hellen \\ W. Kamiri, Matthias Langensiepen, Gunter Menz, Salome Misana, Neema G. Mogha, \\ Bodo Maria Möseler, Emiliana J. Mwita, Helida A. Oyieke \& Nomé Sakané
}

\begin{abstract}
Small wetlands in East Africa are increasingly converted into sites for agricultural production. The resulting changes in land use and cropping systems will impact on the wetlands' vegetation. We characterized the plant communities in four wetlands of Kenya and Tanzania, each comprising four types of land use differentiated by the degree of anthropogenic disturbance (cropland, fallow, grazing land and unused). Since no syntaxonomical scheme was available as a reference, a first classification of vegetation units and the identification of diagnostic species is proposed. We collected 207 relevés in the representative wetlands in relation to the current land uses. The plant communities were determined using a modified TWINSPAN classification. For each vegetation unit, diagnostic species were selected according to their fidelity index (phi coefficient). Floristic relationships between vegetation units were surveyed by nMDS ordination analyses. We identified 15 plant communities and selected 147 diagnostic species. The communities were differentiated into (1) semi-natural wetland vegetation (associated with less disturbed environments), (2) grassland and fallow vegetation, and (3) weed communities (associated with eu-hemerobic, drained and cultivated cropland). While the semi-natural vegetation was distinctly matched with unused fields, the differential matching of the other plant communities with land use types was less clear. According to the floristic similarity, the weed communities associated with cropland tended to be aggregated in the nMDS configuration while the semi-natural vegetation was dispersed. The results of the ordination did not differ when involving all species or only the selected diagnostic ones. As the plant communities described are rankless syntaxa, the establishment of a comprehensive syntaxonomic classification for African wetlands will require further vegetation surveys as well as their comparison with published data.
\end{abstract}

Keywords: flood plain; inland valley; land use; modified TWINSPAN; papyrus swamp.

Nomenclature: African Plant Database (CJB \& SANBI 2010).

Abbreviations: $\mathrm{nMDS}$ = non-metric multidimensional scaling; SWEA = Small Wetlands in East Africa; TWINSPAN = Two-way indicator species analysis.

Received: 14 November 2010 - Accepted: 29 September 2011 - Co-ordinating Editor: Jürgen Dengler.

\section{Introduction}

Wetlands are important landscape elements as they fulfil a diverse set of ecological and social and economic functions. In East Africa, reported wetland services include preservation of biodiversity, pollutant buffering, water supply for consumption and irrigation, sites for hunting and gathering, collection of thatching material and medicinal plants and sites for agricultural production, including cattle grazing and various cropping strategies (Chapman et al. 2001, Denny \& de Ruyter van Steveninck 2001, Junk 2002). Prolonged periods of water (or soil moisture) availability and higher soil fertility in comparison to the surrounding uplands provide a large potential for the expansion and intensification of agricultural production (van der Heyden \& New 2003). However, the conversion of wetlands into sites of agricultural production is threatening their ecological functions, particularly, when conversion is associated with large-scale drainage. Other factors associated with anthropogenic disturbances and driving changes in the plant ecosystems involve eutrophication, pollution and salinization through agrochemicals and waste from settlements, and hydrological changes due to excessive water extraction for industrial or household purposes (Kalinga \& Shayo 1998, Kiai \& Mailu 1998, Junk 2002). These disturbance factors and the associated vegetation forms and species compositions are seen to be used to assess ecosystem health and the wetlands' ability to fulfil ecological functions.

While large wetlands like those of Lake Victoria (Gaudet 1977, Harper et al. 1995) or Lake Naivasha (Kassenga 1997, Kairu 2001) have been the focus of many reviews on the impacts of the land use on their ecological functions, little attention has been paid to the study of vegetation and ecology of East African wetlands with sizes smaller than $10 \mathrm{~km}^{2}$. Such small wetlands show a continuous and seasonally variable transition between aquatic and terrestrial ecosystems and may be permanently or temporary flooded (Aselmann \& Crutzen 1989). Conversion 
of semi-natural wetlands into sites of production will alter the hydrological regime and the trophic level of soils and water, which in turn is likely to affect the vegetation. For a better understanding of the effects of land uses in East African wetlands, it is necessary to characterize the current state of the vegetation in terms of species composition of the phytocoenoses and its relation with different forms of land uses.

While responses of single species to allogenic changes can be used as indicators of disturbance (Gleasonian approach; van der Valk 1981), the first step must involve the characterization of vegetation units (Clemensian approach), which can potentially provide vegetation groups associated with the level of anthropogenic disturbances as well as their interactions with geographical and environmental factors. Assessing the current state of wetland vegetation thus requires the characterization of both the structure and the species composition. One of the most comprehensive methodologies for vegetation classification is offered by phytosociology (Dengler et al. 2008). Resembling traditional subjective procedures, new statistical approaches have been developed to make phytosociological classifications more objective. These may involve the implementation of statistical fidelity measures (Bruelheide 2000, Chytrý et al. 2002, Tichý \& Chytrý 2006, Willner et al. 2009), the improvement of the TWINSPAN algorithm (Roleček et al. 2009), and the development of a specialised software like Juice (Tichý 2002), which executes all mentioned statistical analyses. Additionally Willner (2006) and Dengler et al. (2008) offer conceptual reviews on the association concept and phytosociology, respectively.

In contrast to the situation in Europe where both an established syntaxonomical scheme (Rodwell et al. 2002) and a large number of relevés are available (Schaminée et al. 2009, Dengler et al. 2011), vegetation surveys in Kenya and Tanzania have been mainly carried out in dry ecosystems such as savannas, bushlands and grasslands (Barkham \& Rainy 1976, Bronner 1990, Cornelius \& Schultka 1997). More detailed floristic information is only available for papyrus swamps (Gaudet 1977, Kassenga 1997, Kairu 2001, Owino \& Ryan 2007). However, these studies are based only on a simple listing of plant species or general descriptions of plant formations. The first proposal for a general classification of East African vegetation was made by Phillips (1930). This classification, however, did not follow the criteria of phytosociology, and it is currently outdated. This is particularly true for the small wetlands that are subject to most intense land use dynamics. The integrated research project "Agricultural Use and Vulnerability of Small Wetlands in East Africa" (SWEA) provided the opportunity to improve our knowledge about species commonly encountered in wetlands with different attributes and under various types of land use in Kenya and Tanzania. The main aim of this work was the development of a floristic classification of small wetland vegetation under different land uses and use intensities based on relevés with the aims (1) to derive a vegetation classification according to species composition, (2) to establish the relationships between vegetation units and wetland uses, and (3) to determine the distribution of vegetation communities in different wetlands.

\section{Materials and methods}

\section{Study site}

According to a first survey on geophysical, socio-economical and vegetation attributes of small wetlands in East Africa (Sakané et al. 2011), we selected four contrasting wetlands to cover the prevailing diversity of attributes such as wetland type (floodplain vs. inland valley swamp), altitude (lowland vs. highland), demography (high vs. low population density in the surroundings), and market accessibility (Table 1). Rumuruti is located in the Ewaso Narok floodplain on the Laikipia plateau at $1,811 \mathrm{~m}$ a.s.l. and is characterized by a semi-arid climate. Tegu represents an inland valley wetland of the humid highlands and is located close to Mount Kenya at $1,722 \mathrm{~m}$ a.s.l. The two Tanzanian wetlands are Malinda located in the sub-humid Mkomazi floodplain at $357 \mathrm{~m}$ a.s.l., and Lukozi, an inland valley in the humid Usambara highlands at 1,765 m a.s.l. (Fig. 1).

As no long-term meteorological registers are available for the study sites, we described the respective climate on the basis of data from the interpolation model offered by the International Water Management Institute at http://www.iwmi. cgiar.org/WAtlas (New et al. 2002), combined with own data collected during the field works and registers of meteorological stations located in physical proximity to the study sites. Rainfall in Malinda is concentrated in one rainy season between March and June (Kamiri 2010). Annual rainfall reaches $1,000 \mathrm{~mm}$, while mean monthly temperatures oscillate between $23{ }^{\circ} \mathrm{C}$ in July and $31{ }^{\circ} \mathrm{C}$ in February (mean temperature $25.2^{\circ} \mathrm{C}$ ). The other localities are characterized by a bimodal rainfall pattern, with a long rainy season between March and June and a short rainy season between September and November. In Rumuruti the mean monthly temperatures range between $16^{\circ} \mathrm{C}$ and $20^{\circ} \mathrm{C}$ and the annual precipitation is about 500 mm (Thenya 2001). Monthly temperatures in Tegu are very similar to those in Rumuruti, but the annual precipitation is higher (between 1,000 and 1,500 mm). In Lukozi the monthly temperatures oscillate between $15^{\circ} \mathrm{C}$ and $21^{\circ} \mathrm{C}$ (mean $18.6^{\circ} \mathrm{C}$ ) with an annual precipitation of approximately 1,000 mm (Kamiri 2010).

Table 1: Geographic and physical attributes of the studied wetlands in Kenya and Tanzania. Climate type according to the classification of Köppen.

\begin{tabular}{lcccc}
\hline Wetland & Rumuruti & Tegu & Malinda & Lukozi \\
\hline country & $\mathrm{KE}$ & $\mathrm{KE}$ & $\mathrm{TZ}$ & $\mathrm{TZ}$ \\
coordinates & $0^{\circ} 17^{\prime} 18^{\prime \prime} \mathrm{N}$ & $0^{\circ} 28^{\prime} 26^{\prime \prime} \mathrm{S}$ & $5^{\circ} 06^{\prime} 20^{\prime \prime} \mathrm{S}$ & $4^{\circ} 39^{\prime} 29^{\prime \prime} \mathrm{S}$ \\
Altitude (m a.s.I.) & $36^{\circ} 33^{\prime} 57^{\prime \prime} \mathrm{E}$ & $3^{\circ} 06^{\prime} 08^{\prime \prime} \mathrm{E}$ & $38^{\circ} 20^{\prime} 29^{\prime \prime} \mathrm{E}$ & $38^{\circ} 15^{\prime} 11^{\prime \prime} \mathrm{E}$ \\
landform & 1,811 & 1,722 & 357 & 1,765 \\
area (ha) & flood plain & inland valley & flood plain & inland valley \\
sampled plots & 917.27 & 19.71 & 792.20 & 103.08 \\
climate type & 53 & 42 & 49 & 63 \\
population & $\mathrm{Cwb}$ & $\mathrm{Cwb}$ & $\mathrm{Aw}$ & Cwb \\
market access & dense & sparse & sparse & dense \\
\hline
\end{tabular}



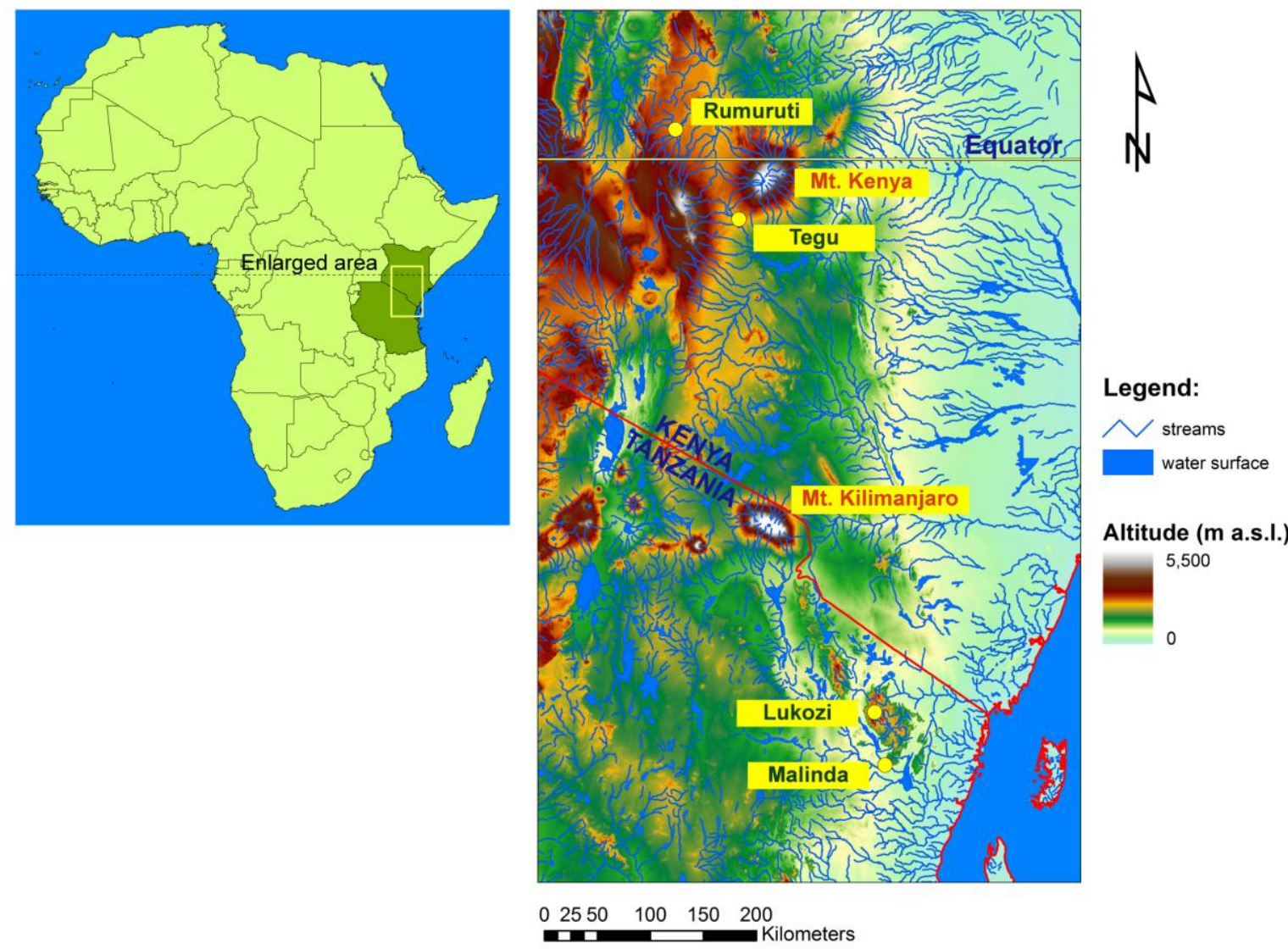

Fig. 1: Location of the studied wetlands (yellow circles) in Kenya and Tanzania. Digital elevation model obtained from the CGIAR-CSI SRTM $90 \mathrm{~m}$ Database (Jarvis et al. 2008). Shape files of lakes, streams, and country borders downloaded from the Digital Chart of the World (URL: http://www.maproom.psu.edu/dcw).

In the Malinda and Rumuruti floodplains, the dominant soil types are Fluvisols and Vertisols, while the inland valley swamps of Tegu and Lukozi are characterized by Gleysols and Histosols, and, in the case of Lukozi, with some colluvial over-lay of gneiss and granite material originating from adjacent steep valley slopes (ARI Mlingano 2006, Kamiri 2010).

While all land use types are encountered at each wetland site, agricultural land use differs between sites with a predominance of intense horticultural production in the peri-urban setting of $\mathrm{Lu}$ kozi, small-scale subsistence food cropping in the rural setting of Tegu, and cattle grazing in the sub-humid and semi-arid savanna environments of Rumuruti and Malinda. Also the type of flood-tolerant crops differs by altitude with lowland rice (Oryza sativa) in Malinda and Taro (Colocasia esculenta) in Tegu (Sakané et al. 2011).

\section{Data collection}

To cover the prevailing diversity of vegetation and land uses in each wetland, the vegetation was sampled in 207 rectangular plots, each measuring $10 \mathrm{~m}^{2}$. The plots were located in areas of homogeneous vegetation, and in the case of cropped fields, were managed by one farmer (preferential sampling; Dengler et al. 2008). The land use of each plot was assessed according to field observations and interviews with the owners and was classified into four main types: (1) crops (cultivated plots), (2) grazing areas, (3) temporarily abandoned fallows, and (4) unused plots dominated by semi-natural vegetation. The species composition of each plot was assessed through relevés according to the Braun-Blanquet method (Wikum \& Shanholtzer 1978, Dengler et al. 2008). All vascular plant species present in each plot were listed and their abundance was recorded following visual estimates of the respective percentage cover. Cover ratings of 6 to $100 \%$ were scaled in $10 \%$ steps, while cover ratings of 1 to $5 \%$ were scaled in $1 \%$ steps. Cover values below $1 \%$ were registered either as sparse (+: more than one individual) or rare (r: only one individual). In farmland plots, the crop species itself was not considered in the estimation of cover. Unknown specimens were collected and identified at the East African Herbarium of the National Museums of Kenya in Nairobi (EA) and at the Herbarium of the University of Daar es Salam in Tanzania (DSM), and using the determination keys of the Flora of Tropical East Africa (Polhill 1949-2010). For sedges and rushes the key of Haines \& Lye (1983) was used. Bryophytes, algae and lichens were not included in the sampling. The relevés were stored in SWEA-Dataveg, a vegetation database in TURBOVEG format (Alvarez et al. 2012). This database is registered with ID AF-00-06 in the Global Index of Vegetation-Plot Databases (GIVD; Dengler et al. 2011). 


\section{Statistical analysis}

For a floristic classification of the relevés stored in SWEA-Dataveg, a vegetation matrix including the original cover values was exported into the Juice software (Tichý 2002) to use the modified TWINSPAN algorithm (Roleček et al. 2009). The minimum group size was set at 3 and the threshold levels of cover were set at $0 \%, 5 \%$ and $50 \%$. Whittaker's beta diversity index (Whittaker 1972) was used for the analysis of heterogeneity of groups, as it provides balanced classifications, respecting group size and heterogeneity, but also because of its robustness (Roleček et al. 2009). The phi coefficient of association was calculated after standardizing the size of the groups according to Tichý \& Chytrý (2006) to compile the lists of diagnostic species for each relevé group derived from the TWINSPAN analysis. To select diagnostic species, we set an arbitrary threshold value of 0.32 , which provided a list of diagnostic species for more than one group that allows the detection of species that link related relevé groups. Only those species were considered as diagnostic that showed a significant concentration in the respective vegetation unit at $\alpha=0.05$ according to Fisher's exact test (Chytrý et al. 2002).

To analyse floristic similarities between the vegetation units, relevés were pooled within groups and the mean value of the percentage cover (absences not considered) and the percentage constancy of each species in each vegetation unit was calculated (importance value; Wikum \& Shanholtzer 1978). The resulting matrix was analyzed using a non-metric multidimensional scaling (nMDS) restricted to two dimensions, to allow an easy visual interpretation of the scatter plot (Lepš \& Šmilauer 2003, Leyer \& Wesche 2007), and measuring the distance between groups according to the Bray-Curtis index (Bray \& Curtis 1957). This index was selected because of its usual robustness when ecological factors are measured (Faith et al. 1987). The same procedure was applied by using only the diagnostic species. Both ordinations (considering all species and only diagnostic ones) were compared using procrustes rotation (Peres-Neto \& Jackson 2001, Olden \& Jackson 2001). The software Juice (Tichý 2002) was applied for the classification analysis, the calculation of the phi coefficient of association, the testing of significance levels, and the edition of the summary tables. Non-metric multidimensional scaling (nMDS) and the procrustes rota- tion were performed in the computing environment $\mathrm{R}$ ( $\mathrm{R}$ Development Core Team 2009), using the package "vegan" (Oksanen et al. 2009).

\section{Results and discussion}

\section{Vegetation units and diagnostic species}

We recorded 400 plant species in the 207 relevés. Of those species, 266 occur in Kenya and 286 in Tanzania. Considering the single localities, 206 species were recorded in Rumuruti (highland floodplain in a semi-arid environment), 188 in Malinda (lowland floodplain in a sub-humid environment), 180 in Tegu, and 152 in Lukozi (both highland inland valley sites). Some 315 species were present in cropped fields, 301 in fallow land, 116 in grazing areas, and 111 in the unused wetland areas. According to the TWINSPAN classification, we obtained 15 relevé groups. Ten of those groups include plots of a single locality with its specific land use, while the other groups cut across several localities or land uses (Table 2). Considering a threshold value of 0.32 for the phi coefficient, 147 diagnostic species were selected for the different vegetation units (Table 3). The number of diagnostic species per vegetation unit ranged from 2 (groups 1 and 3) to 31 (group 5). The relevé groups are described as follows:

\section{Group 1: Typha capensis community}

This group occurred in seven plots and contained two diagnostic species: Epilobium hirsutum and Typha capensis. This is the only cluster containing exclusively unused plots, distributed in both Tanzanian wetland types, the floodplain in Malinda and the inland valleys in Lukozi (Plate D). This vegetation unit has very low species diversity, dominated by $T$. capensis as the common pioneer for eutrophic wetland vegetation.

\section{Group 2: Cyperus papyrus-Cyperus ex- altatus community}

The group was encountered in ten plots and contained nine diagnostic species, namely Cyperus exaltatus, C. papyrus, Grangea maderaspatana, Heliotropium indicum, H. steudneri, Ipomoea aquatica, Mimosa pigra, Phragmites australis, and Trianthema portulacastrum. This group included both fallow plots and unused areas and was mainly associated with oligotrophic permanently flooded sections of floodplains (Plate E). The most impor- tant diagnostic species C. papyrus reached highest cover percentages in undisturbed areas. Despite a low fidelity, Typha capensis was also occasionally encountered in this community, mainly in areas experiencing eutrophication. Other hydrophytes in this group include $\mathrm{Ph}$. australis, M. pigra, C. exaltatus and I. aquatica. From the list of common species associated with papyrus swamps in Lake Naivasha (Gaudet 1977), sole C. papyrus was encountered in the present survey. The occurrence of group 2 in fallow areas of the lowland floodplain in Malinda was associated with areas formerly used for paddy rice production.

\section{Group 3: Cyperus exaltatus-Callitriche oreophila community}

This group was encountered in five plots and contained only two diagnostic species: Callitriche oreophila and Cyperus exaltatus. The group is dominated by grazing areas, all located on the fringe of the highland floodplain of Rumuruti. In general, all species are representing strong anthropogenic disturbances as indicated by the dominance of $C$. exaltatus and the ubiquitous perennial grass Cynodon dactylon.

\section{Group 4: Pennisetum mezianum-} Sporobolus pyramidalis community

This group occurred in ten plots with 13 diagnostic species, namely Cycnium adonense, C. tubulosum, Heliotropium steudneri, Hyphaene compressa, Pennisetum mezianum, Pluchea dioscoridis, Sida acuta, Sphaeranthus steetzii, Sporobolus pyramidalis, Tragia furialis, Vernonia amygdalina, V. colorata, and V. glabra. The group includes plots that were either used as grazing lands or left to fallow and occurred mainly at the two floodplain sites (Malinda and Rumuruti, see Plate C) in semi-arid or sub-humid environments and high densities of grazing cattle. The presence of $S$. pyramidalis and some woody species like $S$. acuta and $H$. steudneri are indicative of the heavy grazing pressure. As in group 3, Cynodon dactylon was frequently associated and sometimes dominating the plots.

\section{Group 5: Pentodon pentandrus-Leersia} hexandra community

Group 5 was encountered in 29 plots. With 31 diagnostic species, this group was the most diverse vegetation unit (mean species richness of 29). Diagnostic species comprised Abildgaardia buchananii, Acmella uliginosa, Asystasia gangetica, Azolla pinnata, Basilicum 
polystachyon, Cyperus distans, C. latifolius, C. laxus, Dryopteris inaequalis, Eclipta prostrata, Enicostema axillare, Ethulia conyzoides, Euphorbia hirta, Ficus sur, Fuirena umbellata, Hibiscus cannabinus, Ipomoea aquatica, I. sinensis, Leersia hexandra, Ludwigia octovalvis, Melanthera scandens, Melochia corchorifolia, Panicum maximum, Pentodon pentandrus, Pluchea dioscoridis, Rhus pyroides, Sesbania speciosa, Sorghum arundinaceum, Torulinium odoratum subsp. auriculatum, Vigna vexillata, and Zehneria scabra. This large species diversity was also reflected in the diverse land uses encountered here comprising fallow plots, croplands, and unused areas. However, all plots occurred in the lowland floodplain of Malinda (Plate F), characterized by a strong seasonality of flooding. Consequently, diagnostic species represented plants typical of an aquatic habitats in the wet season (e.g. A. pinnata, I. aquatica, L. octovalvis and Cyperus spp.) as well as plants of dryer environments typical during the dry season or located on the floodplain fringe (e.g. I. sinensis, a savanna species according to Bronner 1990). This group also includes diverse weed species typically associated with lowland rice (e.g. Leersia hexandra) or occurring in small drainage canals between field plots.

\section{Group 6: Trifolium semipilosum-Sida} schimperiana community

This group occurred in seven plots and comprised 13 diagnostic species: Aeschynomene schimperi, Cyathula uncinulata, Crotalaria juncea, Croton megalocarpus, Echinochloa colona, E. haploclada, Eragrostis tenuifolia, Panicum coloratum, Sida schimperiana, Solanum incanum, Sphaeranthus suaveolens, Trifolium semipilosum, and Vernonia poskeana. While this group was associated with all land uses, it dominated in very wet fallow and grazing areas and was restricted to the highland floodplain site of Rumuruti. The vegetation unit is dominated by grass species of humid environments and Trifolium. semipilosum. Among the typical indicators for high soil moisture are Echinochloa haploclada (mentioned by Phillips 1930 as a typical pioneer grass on moist alluvium) and Sphaeranthus suaveolens (Gaudet 1977). In addition, Croton megalocarpus is a species of the Croton forest (Muasya et al. 1994), which together with other woody species like A. schimperi, S. schimperiana, and $S$. incanum are indicative of

Table 2: Composition of the relevé groups according to the localities (a) and main land uses (b).

\begin{tabular}{|c|c|c|c|c|c|}
\hline \multirow{2}{*}{ Groups } & \multicolumn{4}{|c|}{ (a) Localities } & \multirow{2}{*}{$\begin{array}{l}\text { Plots pe } \\
\text { group }\end{array}$} \\
\hline & Rumuruti & Tegu & Malinda & Lukozi & \\
\hline 1 & - & - & 3 & 4 & 7 \\
\hline 2 & 2 & - & 8 & - & 10 \\
\hline 3 & 5 & - & - & - & 5 \\
\hline 4 & 2 & - & 8 & - & 10 \\
\hline 5 & - & - & 29 & - & 29 \\
\hline 6 & 7 & - & - & - & 7 \\
\hline 7 & - & 4 & - & - & 4 \\
\hline 8 & 22 & - & - & - & 22 \\
\hline 9 & 2 & 38 & - & - & 40 \\
\hline 10 & 8 & - & 1 & - & 9 \\
\hline 11 & 1 & - & - & 16 & 17 \\
\hline 12 & 4 & - & - & - & 4 \\
\hline 13 & - & - & - & 4 & 4 \\
\hline 14 & - & - & - & 3 & 3 \\
\hline 15 & - & - & - & 36 & 36 \\
\hline \multirow[t]{3}{*}{ Total of plots } & 53 & 42 & 49 & 63 & 207 \\
\hline & \multicolumn{4}{|c|}{ (b) Main land uses } & \\
\hline & $\begin{array}{l}\text { Cropping } \\
\text { lands }\end{array}$ & Fallows & $\begin{array}{c}\text { Grazing } \\
\text { lands }\end{array}$ & $\begin{array}{c}\text { Unused } \\
\text { fields }\end{array}$ & $\begin{array}{l}\text { Plots per } \\
\text { group }\end{array}$ \\
\hline 1 & - & - & - & 7 & 7 \\
\hline 2 & - & 6 & - & 4 & 10 \\
\hline 3 & - & 1 & 3 & 1 & 5 \\
\hline 4 & - & 6 & 4 & - & 10 \\
\hline 5 & 12 & 14 & - & 3 & 29 \\
\hline 6 & 2 & 3 & 1 & 1 & 7 \\
\hline 7 & 4 & - & - & - & 4 \\
\hline 8 & 22 & - & - & - & 22 \\
\hline 9 & 20 & 9 & 3 & 8 & 40 \\
\hline 10 & 1 & 4 & 4 & - & 9 \\
\hline 11 & 13 & 4 & - & - & 17 \\
\hline 12 & 4 & - & - & - & 4 \\
\hline 13 & - & 1 & 3 & - & 4 \\
\hline 14 & 1 & 2 & - & - & 3 \\
\hline 15 & 24 & 12 & - & - & 36 \\
\hline Total of plots & 103 & 62 & 18 & 24 & 207 \\
\hline
\end{tabular}

overgrazing in wet environments (Bronner 1990).

\section{Group 7: Sacciolepis africana-} Oxygonum sinuatum community

Goup 7 was restricted to only four plots, however with 22 diagnostic species: $A c a$ cia mearnsii, Ageratum conyzoides, Amaranthus blitoides, Bidens biternatus, Commelina erecta, Crotalaria agatiflora, C. lebrunii, Eragrostis tenuifolia, Galinsoga quadriradiata, Haplosciadium abyssinicum, Justicia betonica, J. flava, Oxalis corniculata, O. latifolia, Oxygonum sinuatum, Melinis repens, Phyllanthus amarus, Physalis peruviana, Sacciolepis africana, Stellaria sennii, Tagetes minuta, and Tephrosia villosa. While group 7 represents a very diverse vegetation unit (mean species richness of 32) it is only associated with maize or vegetable fields in completely drained highland inland valleys. The majority of the diagnostic species in this cluster are typical upland weeds, most of them classified as dry bushland species (Bronner 1990), and many originating from North and South America (e.g. G. quadriradiata, P. peruviana and T. minuta).

\section{Group 8: Sonchus oleraceus-Galinsoga quadriradiata community}

Group 5 was encountered in 22 plots but with only five diagnostic species, namely Crotalaria lebrunii, Galinsoga quadriradiata, Schkuhria pinnata, Sonchus oleraceus, and Trifolium lugardii. Similar to group 7, this cluster included only croplands, however not from an inland valley but rather the highland floodplain of Rumuruti (Plate B). Many of the diagnostic species are also typical upland weeds and the two naming species of the cluster ( $S$. oleraceus and G. quadriradiata) are characteristic of weed communities in Europe (Oberdorfer 2001).

\section{Group 9: Hydrocotyle sibthorpioides community}

This is the largest cluster group, encountered in 40 plots and comprising 23 diagnostic species: Acmella caulirhiza, Agera- 
tum conyzoides, Ammannia baccifera, Lythrum rotundifolium, Coelachne africana, Crassocephalum vitellinum, Cyperus esculentus, Dichondra repens, Galium aparinoides, Gymnanthemum auriculiferum, Hydrocotyle sibthorpioides, Kyllinga brevifolia, K. pumila, Lantana camara, Ludwigia abyssinica, Oxalis corniculata, Panicum trichocladum, Pycreus nigricans, Rorippa nasturtium-aquaticum, Sida ovata, Stellaria sennii, Trifolium rueppellianum, and Triumfetta flavescens. This group occurs in all land uses, however with a predominance of upland field crop plots located in inland valleys (Plate A). Some of the diagnostic species are typical upland or fallow weeds (e.g. A. conyzoides), while the majority are repre- sentative in wet grasslands (e.g. D. repens, H. sibthorpioides, Kyllinga spp. and L. rotundifolium) and Panicum trichocladum is typical for pioneer grass communities in moist, oligotrophic alluvial soils (Phillips 1930). In contrast, Panicum maximum has a broader ecological spectrum ranging from the savanna to lower forest regions (Bronner 1990).

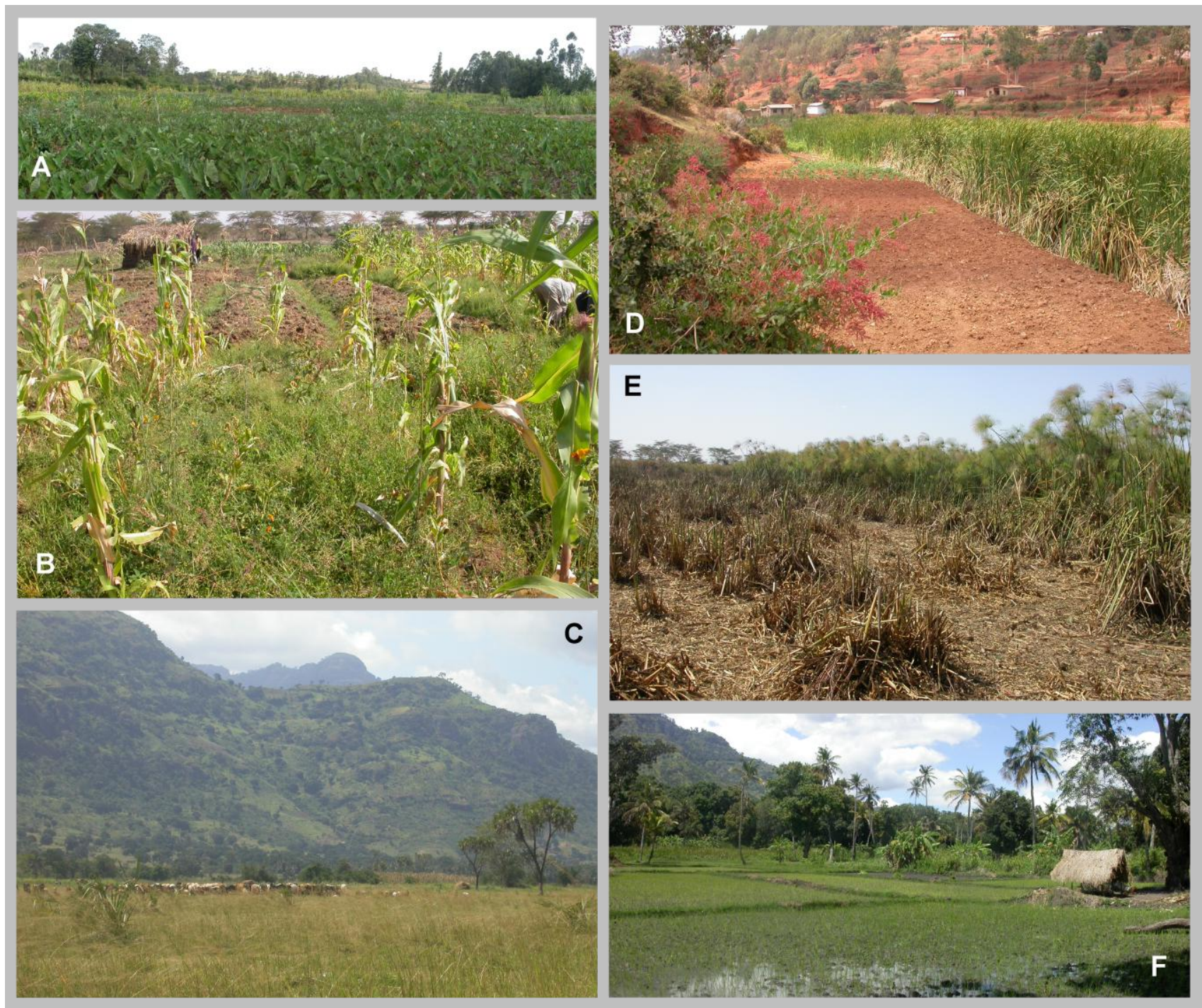

Plate: Pictures of some of the sampled fields in the small wetlands from Kenya and Tanzania.

A: Landscape of the Tegu wetland showing in foreground a taro field (Colocasia esculenta), commonly colonized by the Hydrocotyle sibthorpioides community (Photo M. Alvarez).

B: Field of maize (Zea mays) in Rumuruti with the weeds of the Sonchus oleraceus-Galinsoga quadriradiata community (Photo M. Alvarez).

C: Grassland dominated by Sporobolus pyramidalis in Malinda. Characteristic of this wetland is the doum palm (Hyphaene compressa) with branched trunks. In the background the Usambara Mountains are visible (Photo M. Alvarez).

D: Terrace on the fringe of a Typha capensis stand in Lukozi. In the foreground (left corner) Polygonum usambarensis with its characteristic dark pink flowers can be seen (Photo M. Alvarez).

E: Cyperus papyrus stand in Rumuruti with signs of clearcut and trampling by grazing animals (here mainly cattle) (Photo M. Alvarez).

F: Rice paddies in Malinda. In the background there are also individuals of bananas (Musa paradisiaca), coconut palms (Cocos nucifera), and mangoes (Mangifera indica) (Photo M. Alvarez). 
Table 3: Summary table of the relevé groups showing the constancy (left) and the fidelity (right) of the plant species. Only positive fidelity values (phi coefficient) are shown. Also non-significant fidelity values (according to a Fisher's exact test at $\alpha=0.05$ ) are skipped. The table is shortened, excluding non-diagnostic species (companions). Diagnostic species (values grey-shaded) were selected applying a threshold of phi $\geq 0.32$.

(a) percentage frequency

(b) phi coefficient $\times 100$

Relevé group

$\mathrm{Nr}$. of relevés

Mean nr. of species

Nr. of diagnostic species \begin{tabular}{lllllllllllllll|lllllllllllllll}
1 & 2 & 3 & 4 & 5 & 6 & 7 & 8 & 9 & 10 & 11 & 12 & 13 & 14 & 15 & 1 & 2 & 3 & 4 & 5 & 6 & 7 & 8 & 9 & 10 & 11 & 12 & 13 & 14 & 15
\end{tabular}

\begin{tabular}{llllllllllllllll|lllllllllllllllllll}
7 & 10 & 5 & 10 & 29 & 7 & 4 & 22 & 40 & 9 & 17 & 4 & 4 & 3 & 36 & 7 & 10 & 5 & 10 & 29 & 7 & 4 & 22 & 40 & 9 & 17 & 4 & 4 & 3 & 36
\end{tabular}

\begin{tabular}{lllllllllllllll|lllllllllllllll}
3 & 12 & 8 & 18 & 29 & 27 & 32 & 27 & 32 & 13 & 16 & 27 & 17 & 21 & 24 & 3 & 12 & 8 & 18 & 29 & 27 & 32 & 27 & 32 & 13 & 16 & 27 & 17 & 21 & 24
\end{tabular}

$\begin{array}{llllllllllllllllllllllllllllllll}2 & 9 & 2 & 13 & 31 & 13 & 22 & 5 & 23 & 3 & 7 & 14 & 8 & 5 & 9 & 2 & 9 & 2 & 13 & 31 & 13 & 22 & 5 & 23 & 3 & 7 & 14 & 8 & 5 & 9\end{array}$

Diagnostic species of single groups

Group 1: Typha capensis community

Epilobium hirsutum 43

10060

1038

24

. 64

Group 2: Cyperus papyrus - Cyperus exaltatus community

Cyperus papyrus

Trianthema portulacastrum

Phragmites australis

Heliotropium indicum

Mimosa pigra

Grangea maderaspatana

\begin{tabular}{|c|c|c|}
\hline 100 & 40 & \\
\hline 50 & . & \\
\hline 50 & & 20 \\
\hline 30 & . & 10 \\
\hline 30 & . & 10 \\
\hline
\end{tabular}

Group 3: Cyperus exaltatus -Callitriche oreophila community Callitriche oreophila 20

Group 4: Pennisetum mezianum-Sporobolus pyramidalis community

Pennisetum mezianum

Vernonia colorata

Hyphaene compressa

Vernonia glabra

Sporobolus pyramidalis

Cycnium tubulosum

Vernonia amygdalina

Sida acuta

Sphaeranthus steetzi

Tragia furialis

Cycnium adonense

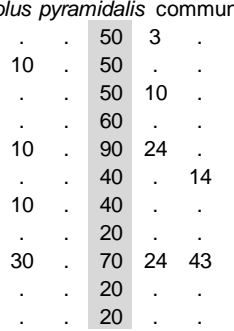

$14 \quad 13 \quad 22 \quad 29$

Group 5: Pentodon pentandrus-Leersia hexandra community Pentodon pentandrus

Melanthera scandens

Ethulia conyzoides

Abildgaardia buchananii

Basilicum polystachyon

Ipomoea sinensis

Ficus sur

Acmella uliginosa

Azolla pinnata

Fuirena umbellata

Enicostema axillare

Cyperus distans

Eclipta prostrata

Hibiscus cannabinus

Panicum maximum

Sorghum arundinaceum

Sesbania speciosa

Melochia corchorifolia

Euphorbia hirta

Asystasia gangetica

Ludwigia octovalvis

Zehneria scabra

Cyperus laxus

Torulinium odoratum subsp.

auriculatum

Dryopteris inaequalis

Rhus pyroides

Vigna vexillata

Cyperus latifolius

Leersia hexandra

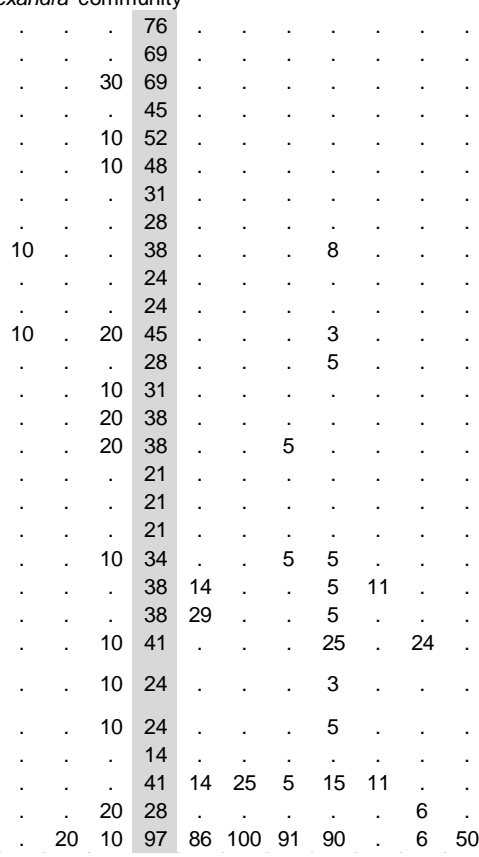




\section{Table 3 (continued).}

Relevé group

(a) percentage frequency

(b) phi coefficient $\times 100$

Diagnostic species of single groups

Group 6: Trifolium semipilosum-Sida schimperiana community

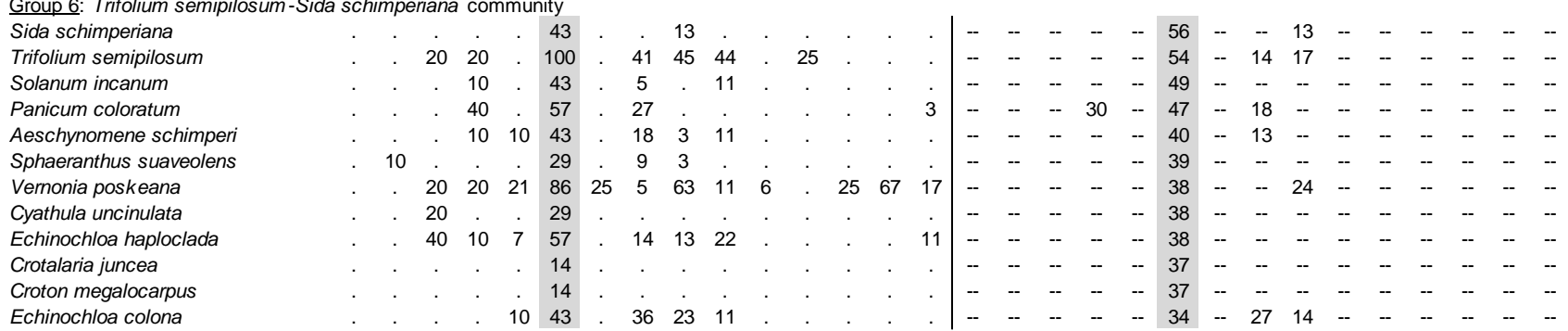

Group 7: Sacciolepis africana-Oxygonum sinuatum community

Acacia mearnsii

Sacciolepis africana

Commelina erecta

Tephrosia villosa

Bidens biternatus

Phyllanthus amarus

Physalis peruviana

Justicia flava

Amaranthus blitoides

Crotalaria agatiflora

Oxalis latifolia

Melinis repens

Oxygonum sinuatum

Justicia betonica

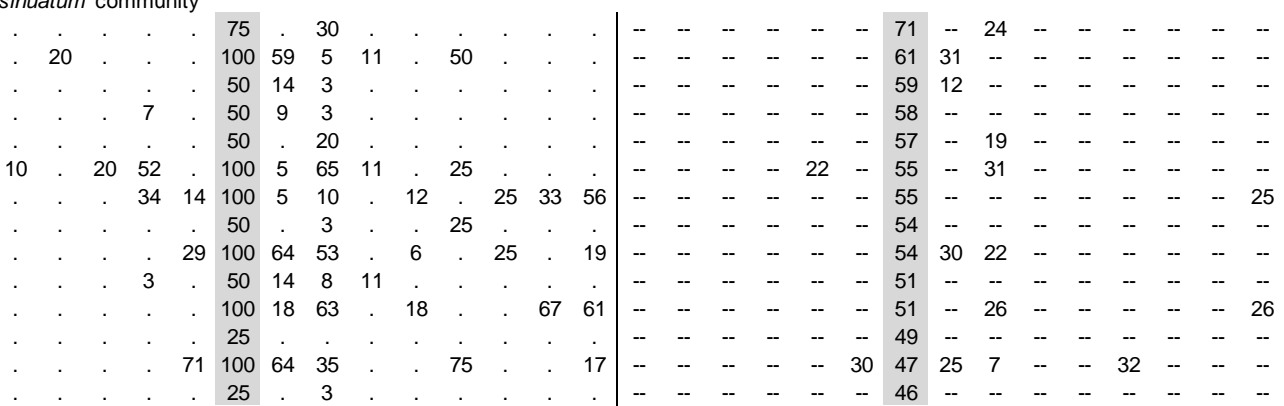

Group 8: Sonchus oleraceus -Galinsoga ciliata community

Trifolium lugardii

Sonchus oleraceus

20

$\begin{array}{cccc}43 & 75 & 95 & 58\end{array}$

\begin{tabular}{cccc|ccccccccc}
50 & 50 & 33 & 3 & -- & -- & - & -- & -- & -- & -- & 41 & - \\
5 & -- & - & -- & -- & -- & - & 40 & 17
\end{tabular}

Group 9: Hydrocotyle sibthorpioides community

Hydrocotyle sibthorpioides

Panicum trichocladum

Dichondra repens

Lythrum rotundifolium

Trifolium rueppellianum

Kyllinga pumila

Crassocephalum vitellinum

Rorippa nasturtium-aquaticum

Acmella caulirhiza

Ludwigia abyssinica

Triumfetta flavescens

Galium aparinoides

Kyllinga brevifolia

Ammannia baccifera

Pycreus nigricans

Coelachne africana

Gymnanthemum auriculiferum

\begin{tabular}{cccc|c}
. &. &. &. & - \\
$\cdot$ &. &. &. & - \\
. &. &. &. & - \\
. & 50 & 33 &. & - \\
. & 50 &. & 6 & - \\
. &. &. &. & - \\
. &. &. &. & - \\
. & 50 & 33 & 14 & - \\
25 & & 33 & 3 & -
\end{tabular}

$\begin{array}{llllllll}40 & 17 & - & -- & -- & -- & -- & --\end{array}$

Sida ovata

Cyperus esculentus

Lantana camara
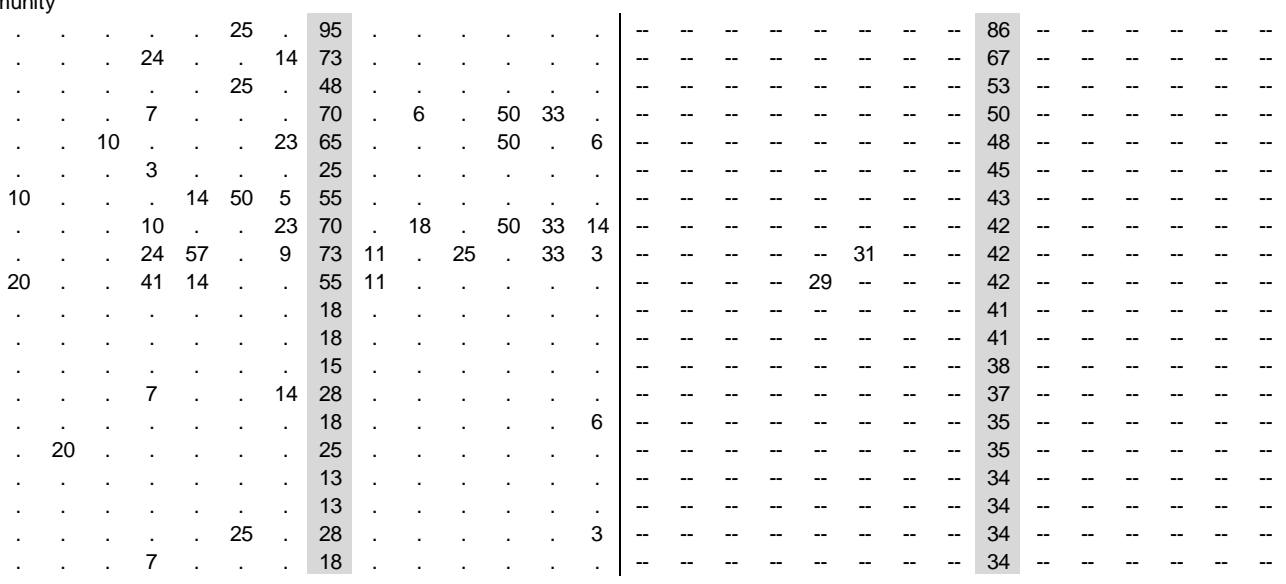

Group 10: Hygrophila auriculata community

Hygrophila auriculata

Acacia elatior

Cirsium vulgare 
Table 3 (continued).

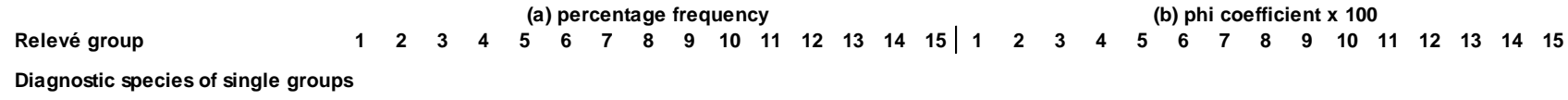

Diagnostic species of single groups

Group 11: Chenopodium opulifolium-Haplosciadium abyssinicum community Amaranthus graecizans

Brachiaria deflexa

Commelina africana

Dactyloctenium geminatum

$\begin{array}{ll}11 & 47 \\ 35\end{array}$

Ambroctenium gemin

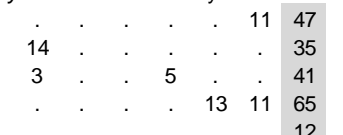

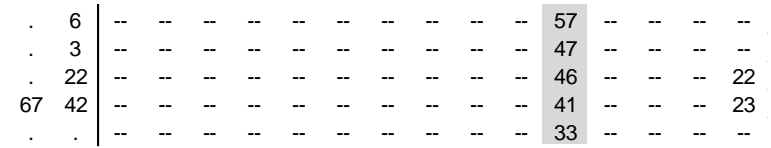

Group 12: Portulaca oleracea-Amaranthus hybridus community

Conyza bonariensis

Veronica anagallis-aquatica

Hibiscus diversifolius

Crambe hispanica

Chloris pilosa

Chenopodium ambrosioides

Dalbergia melanoxylon

Acacia seyal

Cyperus dives

Portulaca oleracea

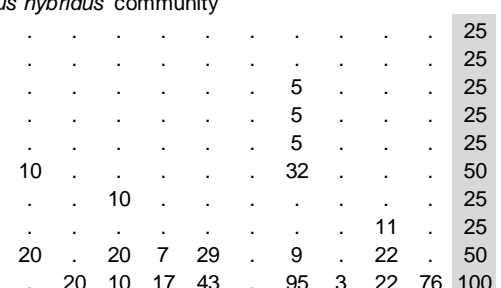

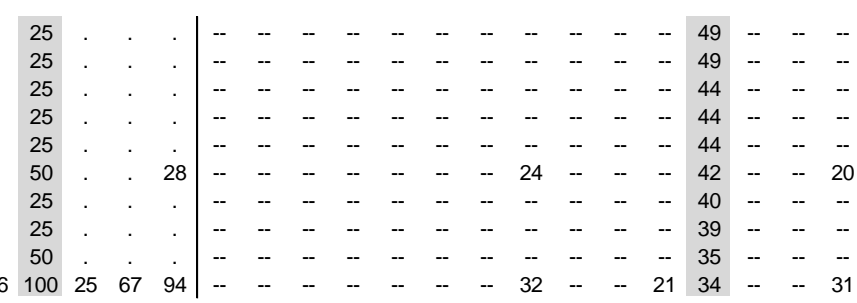

Group 13: Paspalum vaginatum-Chenopodium murale community

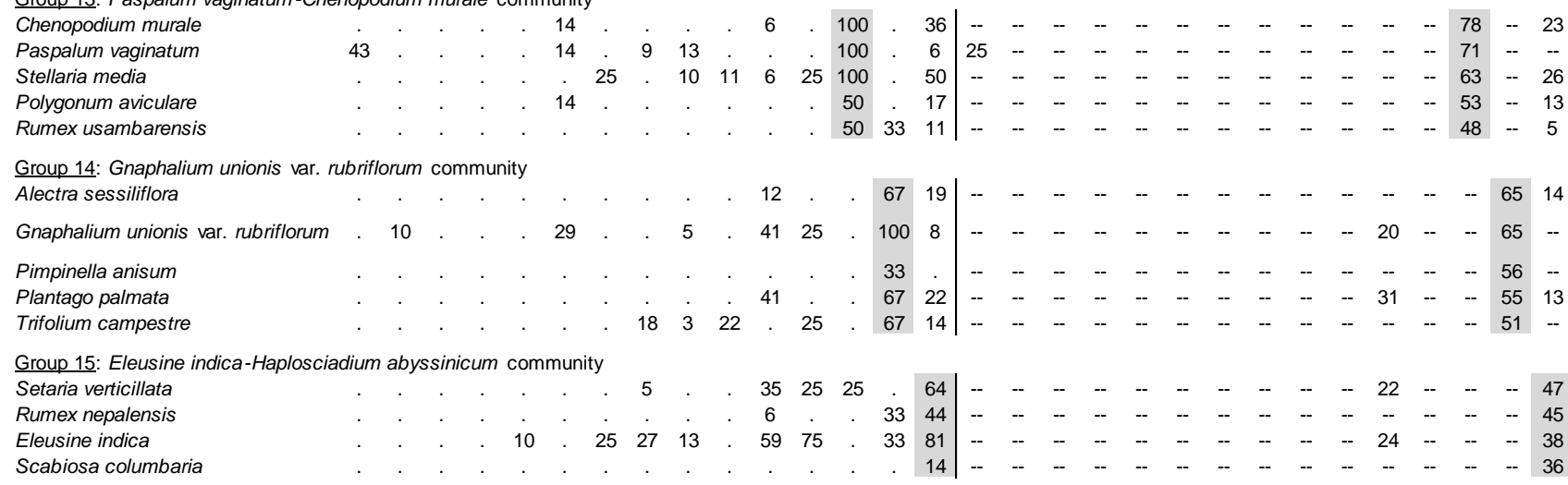

Common diagnostic species of two or more groups

Cyperus exaltatus

Heliotropium steudneri

Ipomoea aquatica

Pluchea dioscoridis

Eragrostis tenuifolia

Galinsoga quadriradiata

Crotalaria lebrunii

Stellaria sennii

Oxalis corniculata

Ageratum conyzoides

Tagetes minuta

Schkuhria pinnata

Chenopodium opulifolium

Datura stramonium

Amaranthus hybridus

Malva parviflora

Chenopodium album

Haplosciadium abyssinicum
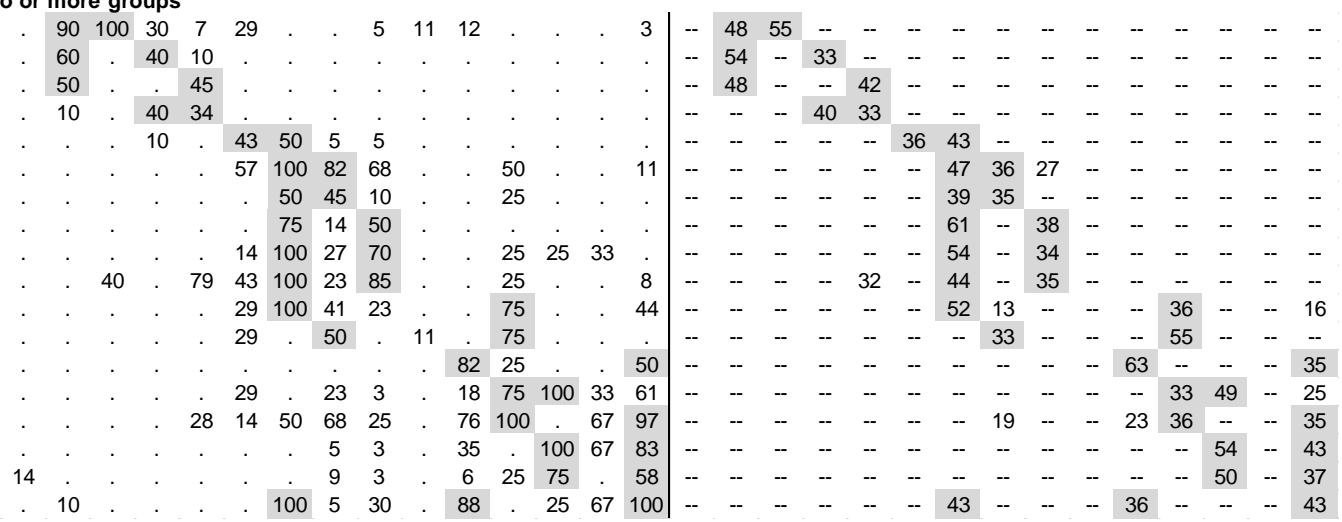

Group 10: Hygrophila auriculata community

This group comprised nine plots and three diagnostic species: Acacia elatior, Cirsium vulgare, and Hygrophila auriculata. This group occurs in fallows and grazing lands during the dry season as well as in the dry fringes of floodplains. Besides the diagnostic species, Cynodon dactylon and Cyperus rotundus are typically associated and frequently dominant species in this community.
Group 11: Chenopodium opulifoliumHaplosciadium abyssinicum community This vegetation unit was encountered in 17 plots with seven diagnostic species: Amaranthus graecizans, Ambrosia maritima, Brachiaria deflexa, Chenopodium opulifolium, Commelina africana, Dactyloctenium geminatum, and Haplosciadium abyssinicum. All plots were located in dry or completely drained fields that were either intensively cropped or had been abandoned to fallow after extended periods of cropping. Accordingly, diagnostic species were typical upland weeds associated with intense vegetable cultivation.

\section{Group 12: Portulaca oleracea- Amaranthus hybridus community}

Group 12 was encountered in four plots with 14 diagnostic species: Acacia seyal, Amaranthus hybridus, Chenopodium ambrosioides, Chloris pilosa, Conyza bonariensis, Crambe hispanica, Cyperus dives, Dalbergia melanoxylon, Datura stramonium, Hibiscus diversifolius, Portulaca oleracea, Schkuhria pinnata, 
Tagetes minuta, and Veronica anagallisaquatica. The group includes exclusively irrigated croplands from the Rumuruti floodplain fringe, mostly cultivated with maize. Accordingly, many of the diagnostic species are annual upland weeds, originating from North and South America (A. hybridus, C. bonariensis, D. stramonium, S. pinnata, and T. minuta). Also some weed species of Eurasian origin were associated with this unit $(C$. abrosioides, C. hispanica, P. oleracea, and $V$. anagallis-aquatica). Like Portulaca oleracea most species are indicating dry conditions or the savanna ecological zone.

Group 13: Paspalum vaginatumChenopodium murale community

This group was encountered in four plots with eight diagnostic species: Chenopodium album, C. murale, Datura stramonium, Malva parviflora, Paspalum vaginatum, Polygonum aviculare, Rumex usambarensis, and Stellaria media. Group 13 is representing a dry grassland vegetation and is only encountered in dry grazing lands or fallow plots of the completely drained inland valleys in Lukozi. Despite the prevalence of dicotyledonous weed species, the dominance of Paspalum vaginatum gives to this community the physiognomy of grassland vegetation.

Group 14: Gnaphalium unionis var. rubriflorum community

Group 14 occurred in only three plots and contained five diagnostic species, namely Alectra sessiliflora, Gnaphalium unionis var. rubriflorum, Pimpinella anisum, Plantago palmata, and Trifolium campestre. This small group (2 fallows and 1 cropland) is restricted to the Lukozi wetland. It represents weed communities in less intensive cultivation, especially in fallows. The naming taxon G. unionis var. rubriflorum is also mentioned for montane forests in the north of Kenya (Bytebier \& Bussmann 2000).

Group 15: Eleusine indicaHaplosciadium abyssinicum community Group 15 is the second largest cluster with 36 plots and nine diagnostic species: Amaranthus hybridus, Chenopodium album, C. opulifolium, Eleusine indica, Haplosciadium abyssinicum, Malva parviflora, Rumex nepalensis, Scabiosa columbaria, and Setaria verticillata. This group is dominated by croplands but includes also some fallows, all located in the inland valley Lukozi. All diagnostic species are typical weeds, many of them originating from Eurasia (C. album, $C$. opulifolium, S. columbaria, and S. verticillata). Also some species common from grasslands are selected as diagnostic species of this unit, for example E. indica and S. verticillata (Phillips 1930). The dominant species here are A. hybridus and $G a$ linsoga parviflora, but the second species is not selected as a diagnostic one.

\section{Ordination analysis and geo- graphical distribution of plant communities}

According to the ordination analysis using all the species, only the weed communities tend to be aggregated, most of them appearing in the upper right side of the nMDS configuration, with the exception of the relevé groups 5, 8 and 9 (Fig. 2a).
Group 1 (Typha capensis community) appears isolated from the rest of the communities due to its strong floristic dissimilarity and to its low species richness. The distribution pattern in this ordination follows only partially the sorting of the groups in the summary table. If we consider only diagnostic species (Fig. 2b), we cannot detect big changes in the nMDS configuration, although in this case we are only considering $37 \%$ of all detected species. This fact suggest that the companion species (non diagnostic) are randomly distributed in the all the communities and do not have a big impact in the floristic similarities. The stress value of the nMDS is less than 0.13 in both ordinations, which is considered as relatively low (Backhaus et al. 2006).

The classification of the relevés as well as the nMDS configuration was strongly influenced by the geographic location, which is probably the most important factor determining the species composition of the communities. We therefore calculated the centroids of the wetlands using the nMDS coordinates of the relevé groups and the frequency of each wetland (Fig. 2b). The distribution of the communities along the wetlands was irregular, many communities were resticted to single wetlands, and none of the communities occurred in all wetlands (Table 4). The variability of plant communities was highest in the Rumuruti floodplain and lowest in the inland valleys of Tegu. The richness on plant communities seems to be influenced by both the wetland size and the diversity in land uses and probably land use intensities.

Table 4: Plant communities described in this work and their presence in the sampled wetlands (Ru: Rumuruti, Te: Tegu, Ma: Malinda, Lu: Lukozi).

\begin{tabular}{|c|c|c|c|c|c|}
\hline Group & Community of... & Ru & Te & Ma & Lu \\
\hline \multicolumn{6}{|c|}{ Wetland vegetation } \\
\hline 1 & Typha capensis & . & . & + & + \\
\hline 2 & Cyperus papyrus-Cyperus exaltatus & + & . & + & . \\
\hline 3 & Cyperus exaltatus-Callitriche oreophila & + & . & . & . \\
\hline \multicolumn{6}{|c|}{ Grassland vegetation } \\
\hline 4 & Pennisetum mezianum-Sporobolus pyramidalis & + & . & + & . \\
\hline 6 & Trifolium semipilosum-Sida schimperiana & + & . & . & . \\
\hline 10 & Hygrophila auriculata & + & . & + & . \\
\hline 13 & Paspalum vaginatum-Chenopodium murale & . & . & . & + \\
\hline \multicolumn{6}{|c|}{ Weed communities } \\
\hline 5 & Pentodon pentandrus-Leersia hexandra & . & . & + & . \\
\hline 7 & Sacciolepis africana-Oxygonum sinuatum & . & + & . & . \\
\hline 8 & Sonchus oleraceus-Galinsoga quadriradiata & + & . & . & . \\
\hline 9 & Hydrocotyle sibthorpioides & + & + & . & . \\
\hline 11 & Chenopodium opulifolium-Haplosciadium abyssinicum & + & . & . & + \\
\hline 12 & Portulaca oleracea-Amaranthus hybridus & + & . & . & . \\
\hline 14 & Gnaphalium unionis var. rubriflorum & . & . & . & + \\
\hline 15 & Eleusine indica-Haplosciadium abyssinicum & . & . & . & + \\
\hline
\end{tabular}




\section{Plant communities and land uses}

Considering the physiognomy and the dominant land uses, we recognize three sets of plant communities: wetland seminatural vegetation, grassland vegetation, and weed communities (Table 4). The three species giving the names to the communities of semi-natural vegetation (Typha capensis, Cyperus papyrus and $C$. exaltatus) are the most important diagnostic species and potential characteristic species of a syntaxa of high rank (alliance, order or class). Although those communities are more or less linked through the mentioned diagnostic species, they appear much dispersed in the nMDS configuration, because those communities are sharing only few diagnostic species. In the case of the Cyperus papyrusCyperus exaltatus community, we can recognize visually in the vegetation matrix (data not shown) two sub-groups, which were not discriminated by TWINSPAN, namely plots dominated by $C$. papyrus and missing all other diagnostic species with the exception of $C$. exaltatus, and plots where $C$. papyrus appears with very low abundance, accompanied by $T y$ pha capensis In a further intent to define associations, we should split this group into the two mentioned sub-groups.

According to our field observations, the stands dominated by papyrus alone represent a more natural situation, while stands of $C$. papyrus with $T$. capensis are more disturbed and show signs of eutrophication. Since all studied wetlands are temporarily flooded, semi-natural communities of floating or submersed plants, like those studied by Harper et al. (1995) are not detected in this survey.

In a schematic way Kamiri (2010) proposed sequences of disturbance or use intensity for each locality mentioning the respective plant communities. The classification of the plots in this work does not give a complete matching with those hypothetical communities. In attention to this, we modify the scheme of disturbance grades under near-permanent flooding conditions, starting with low disturbed communities like those dominated by $T y$ pha capensis or Cyperus papyrus (sub group included in the group 2), the next level of disturbance in both cases is related to the Cyperus papyrus-Cyperus exaltatus community, characterized by a high constancy of both naming species plus $T$. capensis, the third level is a vegetation dominated by $C$. exaltatus (group 3), and advanced levels are indi-

(a) all species

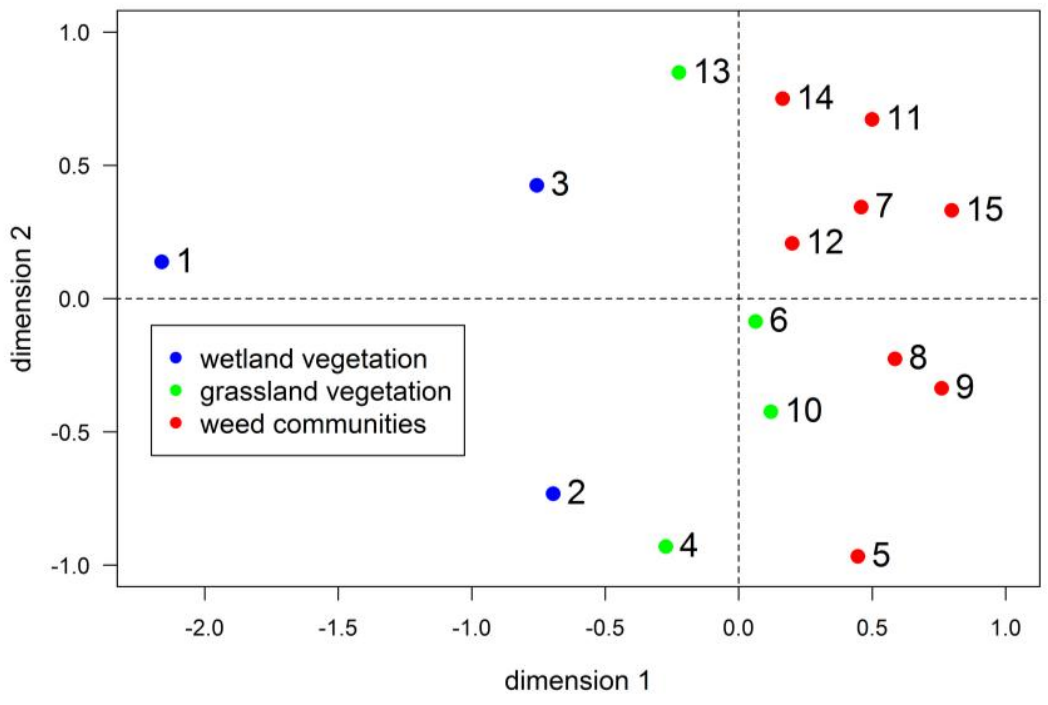

(b) only diagnostic species

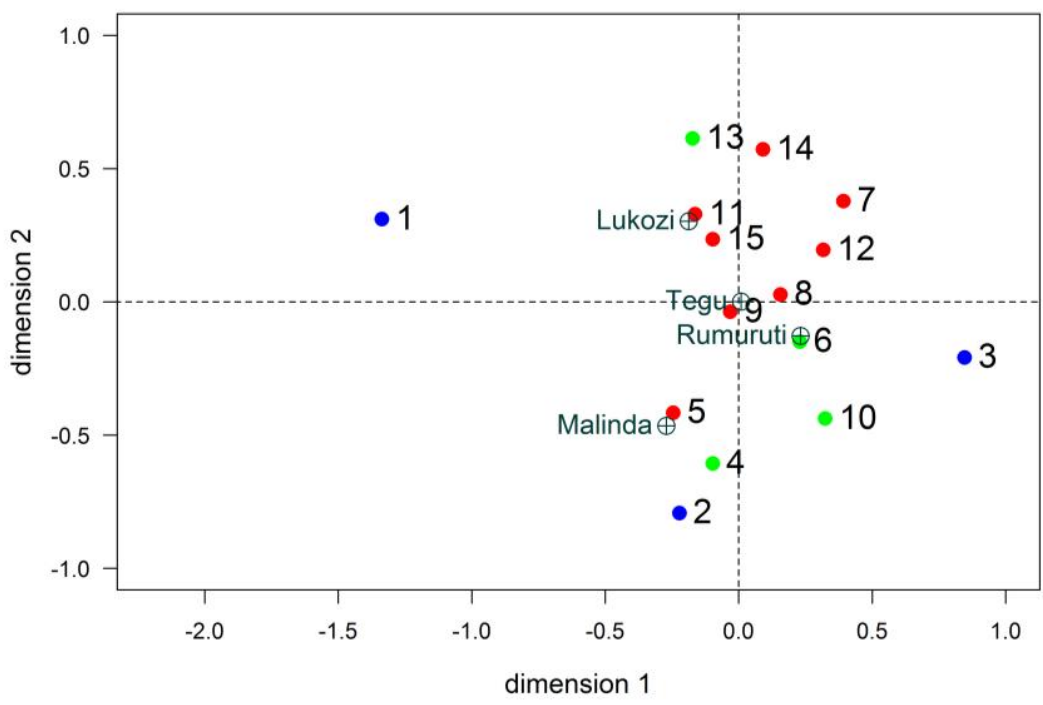

Fig. 2: Configuration of the nMDS showing floristic similarities between relevé groups (numbered as in Table 3). The nMDS analysis was restricted to two dimensions, using Bray-Curtis index as distance metric. The same analysis was applied to the vegetation matrix including all species (a) and only diagnostic species (b). The second ordination diagram was rotated by using the Procrustes method. Centroids of the localities were calculated for the second nMDS configuration, weighting the coordinates by the constancy of relevés from those wetlands. Stress factors: $a=$ $12.78 \%, b=10.86 \%$.

cated by Leersia hexandra (e.g. Pentodon pentandrus-Leersia hexandra community). No syntaxonomical proposals are made for the assignment of papyrus swamps to a syntaxon of high level (class or order). According to the physiognomy but also the floristic composition those communities may be related to the class Phragmito-Magno-Caricetea Klika in Klika \& V. Novák 1941 (Mucina 1997).

The unused plots of the wetland in Tegu were not discriminated in the
TWINSPAN classification and included in the Hydrocotyle sibthorpioides community. Probably the high intensity of cultivation and the small size of this wetland resulted in a high disturbance of the few unused plots. There were also frequent introgressions of weed communities from directly adjacent plots into the wetland plant communities.

Neither fallow plots nor grazing fields appear to be forming discrete vegetation units, suggesting a continuous species 
turnover between both land uses. It was difficult to differentiate between grazing lands and fallows, particularly as most fallow lands were also used for occasional grazing. We recognized four relevé groups as typical grassland vegetation (Table 4) as they were generally close in the nMDS configuration (Fig. 2), with the exception of the Paspalum vaginatumChenopodium murale community. No published floristic studies on weed vegetation in Kenya or Tanzania exist to date. Thus further studies on the use of weed species as indicators of soil conditions and cropping intensity are required. While the present set of weed communities appears well agglomerated in the nMDS configuration, many of the diagnostic species are spread across other communities. Since the Pentodon pentandrusLeersia hexandra community is the only one growing under longer periods of flooding in lowland rice paddies, its floristic differences with other weed communities are due to the environmental conditions contrasting with the otherwise drained fields. The Pentodon pentandrusLeersia hexandra community shares diagnostic species with groups 2 (Cyperus papyrus-Cyperus exaltatus community) and 4 (Pennizetum mezianum-Sporobolus pyramidalis community), all occurring within the lowland floodplain. In this last set, many diagnostic species are mentioned as characteristic for weed vegetation in Europe (Pott 1995, Ellenberg 1996, Oberdorfer 2001), and the most important chorological groups are Eurasia and South and North America. Those plants are mixed in the communities with native species, which also behave as typical weeds. A more detailed survey should elucidate the relation of these vegetation units with the European weed communities, especially those belonging to the class Stellarietea mediae Tx. et al. ex von Rochow 1951 (Mucina 1997, Rodwell et al. 2002).

Calculating the mean Bray-Curtis values of pairwise comparisons, we find a high heterogeneity within relevé groups, with all values ranging bellow 50\% of similarity (data not shown). This heterogeneity can be justified through the high variability of disturbance through cropping or other land uses, which is influencing partially the species composition but especially the relative distribution of abundance values. Additional factors affecting the heterogeneity of the vegetation are the seasonality of the studied phytocoenoses (due to flooding dynamics and cropping) and the heterogeneity of condi- tions within plots, especially in croplands, where wet furrows are alternated with dry mounds. Both factors (temporal and spatial variability) explain the co-occurrence of dryness and humidity indicators in the relevés. In attention to this and the fact that a reference syntaxonomical scheme is missing, we retain the definition of the relevé groups shown here as plant communities (rankless syntaxa). As typical of wetland vegetation, semi-natural stands are relatively poor in plant species (Chambers et al. 2008). Agricultural use of the fields together with disturbances in the soil water balance, especially by mound cultivation (typical of Tegu), terrace construction (in Lukozi) or drainage (in all wetlands) result in an increase of the species richness due to introgression of plants from the neighboring uplands as well as through the introduction of weeds.

\section{Conclusions and outlook}

According to the results presented here, we can classify the vegetation of small wetlands in East Africa floristically into 15 plant communities (syntaxa without specific rank). While undisturbed areas are associated with only few species, more disturbed stands have higher species richness. A strong floristic relationship is exhibited by weed communities, while semi-natural vegetation is dispersed in the nMDS configuration, suggesting a high heterogeneity between communities. However, neither ordination analysis nor selected diagnostic species show clear enough linkages to vegetation units to be used as reference for a hierarchical syntaxonomic classification. More vegetation surveys as well as the extension of SWEA-Dataveg as a regional database will contribute to the establishment of a baseline of a syntaxonomic classification of wetlands in Africa.

\section{Acknowledgements}

The SWEA-project is supported by the Volkswagen Foundation, Hannover, Germany.

\section{References}

Alvarez, M., Möseler, B.M., Josko, M., Becker, M., Langensiepen, M., Menz, G., Böhme, B., Oyieke, H., Handa, C., Kamiri, H., Misana, S., Mwita, E., Neema, M., Sakané, N. (2012): SWEADataveg - vegetation of small wetlands in East Africa. - In: Dengler, J., Oldeland, J., Jansen, F., Chytrý, M., Ewald, J., Finckh, M., Glöckler, F., LopezGonzalez, G., Peet, R.K., Schaminée, J.H.J. (2012) [Eds.]: Vegetation databases for the 21 st century. - Biodiversity \& Ecology 4: 294-295. Hamburg: Biocentre Klein Flottbek and Botanical Garden. CrossRef

ARI Mlingano (2006): Soil map of Tanzania. - Tanga, Tanzania: Mlingano Agricultural Research Institute (ARI Mlingano).

Aselmann, I., Crutzen, P.J. (1989): Global distribution of natural freshwater wetlands and rice paddies, their net primary productivity, seasonality and possible methane emissions. - Journal of Atmospheric Chemistry 8: 307-358. CrossRef

Backhaus, K., Erichson, B., Plinke, W., Weiber, R. (2006): Multivariate Analysemethoden. - Berlin, Germany: Springer.

Barkham, J.P., Rainy, M.E. (1976): The vegetation of the Samburu-Isiolo Game Reserve. - East African Wildlife Journal 14: 297-329.

Bray, J.R., Curtis, J.T. (1957): An ordination of the upland forest communities of southern Wisconsin. - Ecological Monographs 27: 325-349. CrossRef

Bronner, G. (1990): Vegetation and land use in the Mathews Range area, Samburu-District, Kenya. - Dissertationes Botanicae 160: 182 pp. Berlin: Cramer.

Bruelheide, H. (2000): A new measure of fidelity and its application to defining species groups. - Journal of Vegetation Science 11: 167-178. CrossRef

Bytebier, B., Bussmann, R.W. (2000): The vegetation of Mount Nyiru (Samburu District, Kenya): a checklist and syntaxonomical survey. - Journal of East African Natural History 89: 45-71. CrossRef

Chambers, P.A., Lacoul, P., Murphy, K.J. \& Thomaz, S.M. (2008): Global diversity of aquatic macrophytes in freshwater. Hydrobiologia 595: 9-26. CrossRef

Chapman, L.J., Balirwa, J., Bugenyi, F.W.B., Chapman, C., Crisman, T.L. (2001): Wetlands of East Africa: Biodiversity, exploitation and policy perspectives. - In: Gopal, B. [Ed.]: Biodiversity in wetlands: Assessment function and conservation: 101-132. Leiden, The Netherlands: Blackhuys Publishers.

Chytrý, M., Tichý, L., Holt, J., Botta-Dukát, Z. (2002): Determination of diagnostic species with statistical fidelity measures. - Journal of Vegetation Science 13: 79 90.

CJB, SANBI [Conservatoire et Jardin botaniques de la Ville de Genève, South African National Biodiversity Institute] [Eds.] (2010): African Plants Database (version 3.3.4). - URL: http://www.villege.ch/musinfo/bd/cjb/africa [accessed on 2010-10-15].

Cornelius, R., Schultka, W. (1997): Vegetation structure of a heavily grazed 
range in northern Kenya: ground vegetation. - Journal of Arid Environments 36: 459-474. CrossRe

Dengler, J., Chytrý, M., Ewald, J. (2008): Phytosociology. - In: Jørgensen, S.E., Fath, B.D. [Eds.] Encyclopedia of ecology: 2767-2779. Oxford, UK: Elsevier.

Dengler, J., Jansen, F., Glöckler, F., Peet, R.K., De Cáceres, M., Chytrý, M., Ewald, J., Oldeland, J., Finckh, M., Lopez-Gonzalez, G., Mucina, L., Rodwell, J.S., Schaminée, J.H.J., Spencer, N. (2011): The Global Index of VegetationPlot Databases (GIVD): a new resource for vegetation science. - Journal of Vegetation Science 22: 582-597. CrossRef

Denny, P., de Ruyter van Steveninck, E. (2001): Integrated wetland and water resources management capacity building, with special reference to Africa. - In: Bergkamp, G. [Ed.] Integrated wetlands and water resources management: 2936. Gland: IUCN.

Ellenberg, H. (1996): Vegetation Mitteleuropas mit den Alpen. - Stuttgart: Eugen Ulmer.

Faith, D.P., Minchin, P.R., Belbin, L. (1987): Compositional dissimilarity as a robust measure of ecological distance. Vegetatio 69: 57-68. CrossRef

Gaudet, J.J. (1977): Natural drawdown on Lake Naivasha, Kenya, and the formation of papyrus swamps. - Aquatic Botany 3: $1-47$. CrossRef

Haines, R.W., Lye, K.A. (1983): The sedges and rushes of East Africa. - Nairobi, Kenya: East African Natural History Society.

Harper, D.M., Adams, C., Mavuti, K.M. (1995): The aquatic plant communities of the Lake Naivasha wetland, Kenya: pattern, dynamics and conservation. Wetlands Ecology and Management 3: 111-123.

Jarvis, A., Reuter, H.I., Nelson, A., Guevara, E. (2008): Hole-filled SRTM for the globe Version 4. CGIAR-CSI SRTM $90 \mathrm{~m}$ Database. - URL: http://srtm.csi.cgiar. org.

Junk, W.J. (2002): Long-term environmental trends and the future of tropical wetlands. - Environmental Conservation 29: 414-435.

Kairu, J.K. (2001): Wetland use and impact on Lake Victoria, Kenya region. - Lakes and Reservoirs 6: 117-125. CrossRef

Kalinga, G.M., Shayo, E. (1998): Agriculture in the Tanzania wetlands. - URL: http://www.fao.org/docrep/003/x6611e/x 6611e02d.htm [accessed on 2010-0711].

Kamiri, H.W. (2010): Effects of land use dynamics on attributes of wetland soils in Africa. -Bonner Agrikulturchemische Reihe 41. Bonn: INRES, University of Bonn.

Kassenga, G.R. (1997): A descriptive assessment of the wetlands of the Lake Victoria basin in Tanzania. - Resources,
Conservation and Recycling 20: 127141. CrossRef

Kiai, S.P.M., Mailu, G.M. (1998): Wetland classification for agricultural development in Eastern and Southern Africa. URL: http://www.fao.org/DOCREP/003/ x6611E/x6611e02a.htm [accessed on 2010-07-11].

Lepš, J., Šmilauer, P. (2003): Multivariate analysis of ecological data using CANOCO. - Cambridge, UK: Cambridge University Press.

Leyer, I., Wesche, K. (2007): Multivariate Statistik in der Ökologie. - Berlin: Springer

Muasya, J.M., Young, T.P., Okebiro, D.N. (1994): Vegetation map and plant checklist of Al Ari Nyiro ranch and the Mukutan Gorge, Laikipia, Kenya. - Journal of East African Natural History 83: 143197. CrossRef

Mucina, L. (1997): Conspectus of classes of European vegetation. - Folia Geobotanica et Phytotaxonomica 32 117-172. CrossRef

New, M., Lister, D., Hulme, M., Makin, I. (2002): A high-resolution data set of surface climate over global land areas. Climate Research 21: 1-25. CrossRef

Oberdorfer, E. (2001): Pflanzensoziologische Exkursionsflora für Deutschland und angrenzende Gebiete. - Stuttgart: Eugen Ulmer.

Oksanen, J., Kindt, R., Legendre, P., O'Hara, B., Simpson, G.L., Solymos, P., Henry, M., Stevens, H., Wagner, H. (2009): Vegan: community ecology package. - URL: http://www.cran.rproject.org/package=vegan .

Olden, J.D., Jackson, D.A. (2001): Spatial isolation and fish communities in drainage lakes. - Oecologia 127: 572-585. CrossRef

Owino, A.O., Ryan, P.G. (2007): Recent papyrus swamp habitat loss and conservation implications in western Kenya. Wetlands Ecology and Management 15 1-12. $\underline{\text { CrossRef }}$

Peres-Neto P.R., Jackson, D.A. (2001): How well do multivariate data sets match? The advantages of a procrustean superimposition approach over the mantel test. - Oecologia 129: 169-178. CrossRef

Phillips, J. (1930): Some important vegetation communities in the central province of Tanganyika territory (formerly German East Africa) - a preliminary account. Journal of Ecology 18: 193-234. CrossRef

Polhill, R.M. (1949-2010) [Ed.]: Flora of tropical East Africa. - London: Royal Botanic Gardens, Kew.

Pott, R. (1995): Die Pflanzengesellschaften Deutschlands. - Stuttgart: Eugen Ulmer.

R Development Core Team (2009): R: a language and environment for statistical computing. R Foundation for Statistical Computing, Vienna, Austria. - URL: http://www.cran.r-project.org.
Rodwell, J.S., Schaminée, J.H.J., Mucina, L., Pignatti, S., Dring, J., Moss, D. (2002): The diversity of European vegetation - an overview of phytosociological alliances and their relationships to EUNIS habitats. - Wageningen, The Netherlands: National Reference Centre for Agriculture, Nature and Fisheries.

Roleček, J., Tichý, L., Zelený, D., Chytrý, M. (2009): Modified TWINSPAN classification in which the hierarchy respects cluster heterogeneity. - Journal of Vegetation Science 20: 596-602.

Sakané, N., Alvarez, M., Becker, M., Böhme, B., Handa, C., Kamiri, H.W., Langensiepen, M., Menz, G., Misana, S., Mogha, N.G., Möseler, B.M., Mwita, E.J., Oyieke, H.A., van Wijk, M.T. (2011): Classification, characterisation, and use of small wetlands in East Africa. - Wetlands. 31: 1103-1116.

Schaminée, J.H.J., Hennekens, S.M., Chytrý, M., Rodwell, J.S. (2009): Vegetation-plot data and databases in Europe: an overview. - Preslia 81: 173185.

Thenya, T. (2001): Challenges of conservation of dryland shallow waters, Ewaso Narok swamp, Laikipia District, Kenya. Hydrobiologia 458: 107-119. CrossRef

Tichý, L. (2002): JUICE, software for vegetation classification. - Journal of Vegetation Science 13: 451-453.

Tichý, L., Chytrý, M. (2006): Statistical determination of diagnostic species for site groups of unequal size. - Journal of Vegetation Science 17: 809-818.

van der Heyden, C.J., New, M.G. (2003): The role of a dambo in the hydrology of a catchment and the river network downstream. - Hydrology and Earth System Sciences 7: 339-357.

van der Valk, A.G. (1981): Succession in wetlands: a Gleasonian approach. Ecology 62: 688-696. CrossRef

Whittaker, R.H. (1972): Evolution and measurement of species diversity. Taxon 21: 213-251. CrossRef

Wikum, D.A., Shanholtzer, G.F. (1978): Application of the Braun-Blanquet coverabundance scale for vegetation analysis in land development studies. - Environmental Management 2: 323-329. CrossRef

Willner, W. (2006): The association concept revisited. - Phytocoenologia 36: 67-76. CrossRef

Willner, W., Tichý, L., Chytrý, M. (2009): Effects of different fidelity measures and contexts on the determination of diagnostic species. - Journal of Vegetation Science 20: 130-137. CrossRef 
Miguel Alvarez* (malvarez@unibonn.de), Matthias Josko (josko@unibonn.de) \& Bodo M. Möseler (moeseler@uni-bonn.de) Vegetation Ecology, INRES, University of Bonn

Nußallee 9

53115 Bonn, GERMANY

Mathias Becker (mathias.becker@unibonn.de)

Plant Nutrition, INRES, University of

Bonn

Karlrobert-Kreiten-Str. 13

53115 Bonn, GERMANY

Matthias Langensiepen (mlang@unibonn.de)

Crop Science, INRES, University of Bonn Katzenburgweg 5 53115 Bonn, GERMANY
Gunter Menz (g.menz@geographie.unibonn.de)

Geographical Institute, University of Bonn

Meckenheimer Allee 166

53115 Bonn, GERMANY

Beate Böhme (beate.boehme@tbt.tufreiberg.de)

Soil and Water Conservation Unit, TU

Bergakademie Freiberg

Agricolastr. 22

09599 Freiberg, GERMANY

Salome Misana (smisana@ud.co.tz)

Neema G. Mogha (moghang@yahoo.com)

\& Emiliana J. Mwita

(emmyrh@yahoo.com)

Geography, DUCE, University of Dar es

Salaam

P.O. Box 35049

Dar es Salaam,TANZANIA
Collins Handa (handacollins@gmail.com) \& Helida A. Oyieke

(cbd@museums.or.ke)

National Museums of Kenya, Museums

Hill Road

P.O. Box 40658-00100

Nairobi, KENYA

Hellen W. Kamiri

(wangechikamiri@yahoo.com)

Karatina University College

Moi University

P.O. Box 1957-10101

Karatina, KENYA

Nomé Sakané (nsakana@gmail.com) Plant Production Systems, University of Wageningen

P.O. Box 430

6700 AK Wageningen, NETHERLANDS

*Corresponding author 